ТРИБУНА МОЛОДОГО УЧЕНОГО

\title{
TRIBUNE FOR YOUNG SCIENTISTS
}

УДК 343.98

DOI 10.33184/pravgos-2020.4.38

\author{
О РОЛИ ЦИФРОВИЗАЦИИ В РЕГУЛИРОВАНИИ \\ ПЕРЕЧНЯ СУДЕБНЫХ ЭКСПЕРТИЗ, ПРОВОДИМЫХ \\ ВНЕ ГОСУДАРСТВЕННЫХ СУДЕБНО-ЭКСПЕРТНЫХ \\ ОРГАНИЗАЦИЙ
}

\author{
АБДУЛЛИН Руслан Рамилевич, \\ аспирант кафедры криминалистики Института права Башкирского \\ государственного университета, судья Орджоникидзевского районного \\ суда г. Уфы, г. Уфа, Россия. \\ E-mail: kriminalist2010@mail.ru
}

Изучение практики расследования преступлений свидетельствует о необходимости использования достижений высоких технологий, выраженных в самой передовой форме - цифровизации. Возможности цифровизации внедряются и в судебно-экспертную деятельность, в том числе в деятельность негосударственных судебно-экспертных организаций. Цель: анализ проблем нормативного, научно-методического, материально-технического регулирования перечня судебных экспертиз, проводимых вне государственных судебно-экспертных организаций, с разработкой путей их решения. Методы: эмпирические методы наблюдения, сравнения, описания, интерпретации, толкования правовых норм, сравнительно-правового и статистического анализа, формально-логические методы научного познания. В результате проведенного исследования различных подходов, анализа отечественных и зарубежных нормативно-правовых актов доказана необходимость разработки перечня судебных экспертиз, запрещенных к производству вне государственных судебно-экспертных организаций, что позволило определить пути повышения уровня цифровизации судебных экспертиз за счет совершенствования правового, научнометодического и организационного обеспечения судебно-экспертной деятельности в Российской Федерации. 
Ключевые слова: судебно-экспертная деятельность; эксперт; негосударственные судебно-экспертные организации; цифровизация; высокотехнологичные методы; перечень экспертиз.

Согласно данным ГИАЦ МВД России с января по август 2020 г. совершено 1367400 преступлений, что на 0,9\% больше, чем за аналогичный период прошлого года. Особенно тревожит рост тяжких и особо тяжких преступлений. Их удельный вес от общего числа зарегистрированных преступлений вырос с 24,5 до 27,4 \% ${ }^{1}$. В этих статистических данных отражается вся сложность криминогенной обстановки в стране, которая требует принятия действенных мер со стороны государства и общества.

Одним из самых значимых направлений в расследовании и раскрытии преступлений, как и в гражданском, арбитражном, административном процессах, является формирование доказательственной базы для дальнейшего отправления правосудия. Существенная роль в исследовании доказательств отводится судебной экспертизе. При этом отметим, что судебные экспертизы законодательством предписано проводить в судебно-экспертных организациях восьми государственных ведомств (МВД, ФСБ, Министерство обороны, Министерство юстиции, Министерство здравоохранения, МЧС, ФТС и СК РФ), а также в негосударственных судебно-экспертных организациях, частными экспертами и лицами, привлекаемыми в качестве экспертов, но работающими в учреждениях, не являющихся экспертными. Причем роль негосударственных судебно-экспертных организаций является значительной во всех видах судопроизводства. Так, за 6 месяцев 2020 г. 59,4 \% определений о назначении судебных экспертиз в гражданском процессе и 80,6 \% постановлений в административном процессе вынесены в адрес негосударственных экспертных организаций ${ }^{2}$.

Эксперты негосударственных судебно-экспертных организаций, сертифицированные Институтом повышения квалификации Союза «Палата судебных экспертов им. Ю.Г. Корухова (СУДЭКС)», проводят судебные экспертизы по 56 экспертным специальностям (родам и видам судебных экспертиз $)^{3}$, в то время как экспертно-криминалистическими под-

${ }^{1}$ Состояние преступности в России за январь - август 2020 г. [Электронный реcypc]. URL: https://мвд.pф/reports/item/21244698 (дата обращения: 02.11.2020).

${ }^{2}$ Данные судебной статистики // Судебный департамент при Верховном Суде PФ [Электронный pecypc]. URL: http://www.cdep.ru/index.php?id=79\&item=5461 (дата обращения: 03.11.2020).

${ }^{3}$ Все экспертные специальности: Институт повышения квалификации // Палата судебных экспертов им. Ю.Г. Корухова [Электронный ресурс]. URL: https://www. sudex.ru/specialities (дата обращения: 03.11.2020). 
разделениями МВД РФ проводятся экспертизы по 49 экспертным специальностям ${ }^{1}$, экспертами федеральных бюджетных судебно-экспертных учреждений Министерства юстиции РФ - по 56 экспертным специальностям $^{2}$. Из этого обширного перечня выполняемых экспертными организациями судебных экспертиз в современную эпоху повышения уровня интеллектуализации и технологизации криминальной деятельности, цифровизации социально-экономических процессов все большее место стали занимать судебные экспертизы, требующие использования высокотехнологичных средств и методов [1, с. 14]. К использованию таких высокотехнологичных экспертных средств и методов предъявляются высокие требования, в частности разработка программного обеспечения компьютерного решения типовых экспертных задач, разработка автоматизированного поиска информации при решении диагностических экспертных задач, разработка правил цифровизации отдельных видов судебных экспертиз, разработка цифровизованных рабочих мест (ЦРМ) эксперта и др. В этой связи имеются проблемы, одна из которых особенно острая. Это проблема перечня судебных экспертиз, которые могут проводиться вне государственных судебно-экспертных организаций.

В настоящее время ограничения, связанные с запретом производства отдельных видов и родов судебных экспертиз вне государственных судебно-экспертных организаций, законодательно закреплены в ряде стран. Так, в Законе Украины «О судебной экспертизе» от 25 февраля 1994 г. № 4038а-ХІІ в ст. 7 «Субъекты судебно-экспертной деятельности» указано, что криминалистические, судебно-медицинские и судебнопсихиатрические экспертизы проводятся «исключительно государственными специализированными учреждениями» ${ }^{3}$. В Республике Казахстан в особых, оговоренных законом случаях допускается назначение иным лицам в разовом порядке судебной экспертизы, не предусмотренной переч-

${ }^{1}$ Вопросы определения уровня профессиональной подготовки экспертов в системе МВД России : приказ МВД России от 09.01.2013 № 2 (ред. от 27.06.2019) [Электронный ресурс] // Доступ из справ.-правовой системы «КонсультантПлюс» (дата обращения: 26.10.2020).

${ }^{2}$ Об утверждении Перечня родов (видов) судебных экспертиз, выполняемых в федеральных бюджетных судебно-экспертных учреждениях Минюста России, и Перечня экспертных специальностей, по которым представляется право самостоятельного производства судебных экспертиз в федеральных бюджетных судебно-экспертных учреждениях Минюста России : приказ Минюста России от 27.12.2012 № 237 (ред. от 13.09.2018) [Электронный ресурс] // Доступ из справ.-правовой системы «КонсультантПлюс» (дата обращения: 26.10.2020).

${ }^{3}$ Про судову експертизу : Закон Украины от 25.02.1994 № 4038а-ХІІ [Электронный pecypc]. URL: https://zakon.rada.gov.ua/laws/show/4038-12 (дата обращения: 26.10.2020). 
нем видов судебных экспертиз, установленным Министерством юстиции Республики Казахстан.

Судебно-экспертные организации Российской Федерации, независимо от принадлежности их к различным видам собственности, в настоящее время не имеют законодательного запрета на производство конкретных видов и родов судебных экспертиз. В то же время вполне обоснованной считается необходимость проведения ряда родов судебных экспертиз с соблюдением определенных требований, предъявляемых к специальному оснащению помещений, которые должны соответствовать стандартам и требованиям, утвержденным федеральным исполнительным органом власти. Такими экспертизами являются судебно-баллистические и судебные экспертизы наркотических средств, психотропных веществ и их прекурсоров, сильнодействующих и ядовитых веществ, лекарственных средств. Это вполне естественно, так как кроме высокотехнологичного оборудования для хранения объектов, исследуемых в ходе производства данных родов судебных экспертиз, необходимы специальные помещения со специфической структурой стен, полов, потолка, а также наличие специальных хранилищ со строго соблюдаемыми характеристиками состава воздушной среды и материалов внутри хранилищ и т. д. Поэтому эти виды судебных экспертиз, как и экспертизы взрывчатых веществ, их продуктов, взрывных устройств и следов их взрыва, порохов, пиротехнических составов и следов их сгорания, категорически рекомендовано не проводить вне государственных судебно-экспертных организаций. Кроме того, имеются роды и виды судебных экспертиз, проведение которых возможно только в условиях стационарных подразделений судебно-экспертных организаций. Так, производство судебно-психиатрических экспертиз регламентировано проводить только в строго изолированных от внешнего мира отделениях судебно-психиатрических экспертиз на территории психиатрических больниц, причем комиссиями в составе трех штатных врачей-психиатров.

В условиях все большего использования цифровых информационных технологий в судебно-экспертной деятельности еще одним критерием возможности (невозможности) проведения тех или иных видов судебных экспертиз вне государственных судебно-экспертных организаций становится степень владения экспертами новыми научно-методическими разработками и современным оборудованием. Например, ученые Института биохимии и генетики Уфимского федерального исследовательского центра РАН разработали высокотехнологичный метод «оцифровки в бинарном формате сразу всей четверки нуклеотидов в каждом снипе, обладающий целым рядом важных преимуществ» [2, с. 97]. Данным методом 
достигнут высокий «уровень цифровизации: объем введенной в базу данных информации при ДНК-идентификации личности с помощью снипов составляет для одного человека не более 1 килобайта (с помощью STRлокусов - более 200 килобайт)» [3, с. 16-17]. Для применения данного метода цифровизации авторами разработано соответствующее программное обеспечение для проведения цифровизации однонуклеотидного полиморфизма ДНК в виде конкретных выбранных для соответствующей панели высокополиморфных снипов, служащей для ДНК-идентификации личности. Из приведенного примера, становится вполне очевидным, что такие высокотехнологичные исследования возможны только с использованием современного оборудования сотрудниками высокой степени научно-методической подготовки. Анализ экспертной практики свидетельствует, что такое сложнейшее оборудование, программное обеспечение и специалисты в негосударственных судебно-экспертных организациях (и среди частных экспертов) отсутствуют. Отсюда следует, что судебные генотипоскопические (молекулярно-генетические) экспертизы должны проводиться только в государственных судебно-экспертных организациях, в особых сложных случаях - с приглашением ведущих сотрудников научно-исследовательских институтов.

В то же время в условиях постоянного реформирования судопроизводства в Российской Федерации, в ходе которого «продолжается введение ... новелл, ориентированных на гуманизацию уголовного процесса, равноправие и состязательность сторон» [4, с. 7], имеется настоятельная необходимость в дальнейшем совершенствовании высокотехнологичной деятельности и негосударственных судебно-экспертных организаций. И такое движение, хотя и малыми темпами, имеет место. Например, директор одного из негосударственных судебно-экспертных организаций О.И. Плетень разработал методику определения давности создания объекта, содержащего целлюлозу, с использованием импульсной ЯМР-спектроскопии. Способ, на котором основана данная методика, автор запатентовал в США. Отметим, что давность исполнения документа, устанавливаемая при помощи этой методики, не ограничена, «искусственное старение документа не создает помех для точного определения даты исполнения документа с точностью до 15 дней» [5, с. 11]. Таким образом, и вне государственных судебно-экспертных организаций могут проводиться не только высокотехнологичные судебные экспертизы с высоким уровнем цифровизации исследовательского процесса, но и разработки современных экспертных методик.

Многолетний анализ следственной, судебной и экспертной практики позволяет сделать вывод о том, что сотрудниками негосударственных су- 
дебно-экспертных организаций и частными экспертами на достаточно удовлетворительном уровне проводятся судебные почерковедческие, техникокриминалистические, трасологические, портретные, автотехнические, строительно-технические, экономические, оценочные и ряд других родов судебных экспертиз. А процесс цифровизации судебно-экспертной деятельности постепенно привел к улучшению научно-методического обеспечения, к увеличению возможностей судебных экспертов. И многие судебные экспертизы экспертами обозначенных организаций проводятся с применением высокого уровня цифровизации. Например, строительно-техническая экспертиза проектов строений в настоящее время представляет собой исследование данных, которые «сами по себе стали активом, имеющим новую форму представления - цифровую» [6, с. 18]. Еще одним родом судебных экспертиз, успешно выполняемых вне государственных судебно-экспертных организаций на высоком цифровом уровне, является судебная дендрохронологическая экспертиза, которую проводят в основном частные эксперты с использованием APM, состоящего из оборудования фирм «Haglof» и «Suunto», компьютерного комплекса «Lintab», программного обеспечения «TSAP» для обработки измерений трирадиусов.

Но такие случаи скорее исключение, чем закономерность в деятельности негосударственных судебно-экспертных организаций. К сожалению, не все виды и роды судебных экспертиз выполняются экспертами вне государственных судебно-экспертных организаций в соответствии с требованиями ст. 4 Федерального закона от 31 мая 2001 г. № 73-Ф3 «О государственной судебно-экспертной деятельности» об использовании современных достижений науки и техники. Качество высокотехнологичных видов и родов судебных экспертиз, проводимых сотрудниками негосударственных судебных организаций и частными экспертами, остается низким из-за наличия следующих экспертных ситуаций:

- негосударственные судебно-экспертные организации обладают техническими возможностями и оборудованием, но не имеют в своем составе высококвалифицированных экспертов;

- негосударственные судебно-экспертные организации имеют в своем составе высококвалифицированных экспертов, но не обладают техническими возможностями и оборудованием;

- негосударственные судебно-экспертные организации не обладают техническими возможностями и оборудованием и не имеют в своем составе высококвалифицированных экспертов;

- негосударственные судебно-экспертные организации обладают техническими возможностями и оборудованием и имеют в своем составе 
высококвалифицированных экспертов, но не обладают современными методиками проведения судебных экспертиз определенных видов.

По нашему мнению, независимо от названных ситуаций необходим законодательный запрет на производство вне государственных судебноэкспертных организаций следующих видов и родов судебных экспертиз:

1) судебные экспертизы наркотических средств, психотропных веществ и их прекурсоров, сильнодействующих и ядовитых веществ, лекарственных средств;

2) судебно-баллистические экспертизы;

3) взрывотехнические экспертизы (экспертизы взрывчатых веществ, их продуктов, взрывных устройств и следов их взрыва, порохов, пиротехнических составов и следов их сгорания);

4) судебно-психиатрические экспертизы.

Кроме перечисленных рекомендуем запретить проводить в негосударственных судебно-экспертных организациях и частными экспертами виды и роды судебных экспертиз, требующие затратных цифровых информационных технологий и цифровизации научно-методического обеспечения, которые возможны только в рамках финансирования государственных научно-исследовательских программ:

- судебные генотипоскопические экспертизы (исследование ДНК);

- судебные экспертизы радиоэлектронных устройств и сетей;

- судебные фоноскопические экспертизы (исследование голоса и звучащей речи);

- судебная экспертиза специальных маркирующих веществ.

Перечень видов и родов судебных экспертиз, проводимых вне государственных судебно-экспертных организаций, в связи с дальнейшим повышением уровня цифровизации судебно-экспертной деятельности будет постоянно изменяться с учетом следующих причин:

a) в ходе изучения и применения передового зарубежного опыта, судя по всему, предвидится большее использование возможностей научно-исследовательских учреждений и факультетов вузов в производстве сложных высокотехнологичных судебных экспертиз;

б) в результате составления единого федерального реестра экспертных методик и их цифровизации будет обеспечена их доступность для всех судебно-экспертных организаций;

в) в результате внедрения искусственной нейронной сети для проведения судебных экспертиз отдельных видов и родов;

г) в результате аккредитации всех судебно-экспертных организаций (лабораторий) в соответствии с международным стандартом ISO/IEC 
17025 и разработкой и утверждением межгосударственных стандартов по судебным экспертизам;

д) в результате увеличения финансирования научно-исследовательских и опытно-конструкторских работ по цифровизации судебноэкспертной деятельности.

Представляется, что, уделяя повышенное внимание цифровизации при одновременном совершенствовании правового, научно-методического и организационного обеспечения судебно-экспертной деятельности, будет сформирован оптимальный перечень судебных экспертиз, проводимых вне государственных судебно-экспертных организаций, что будет способствовать повышению качества судебных экспертиз и, соответственно, всего судопроизводства в нашей стране.

\section{Библиографический список}

1. Аминев Ф.Г., Чемерис А.В. О новых методах цифровизации при проведении генотипоскопической экспертизы и геномной регистрации населения Российской Федерации // Цифровой след как объект судебной экспертизы : матер. Междунар. науч.-практ. конф., 17 янв. 2020 г. / ред. колл.: Е.Р. Россинская, А.К. Лебедева, М.С. Чернявская. М. : Проспект, 2020. С. 14-18.

2. Аминев Ф.Г. О необходимости принятия федерального закона «О всеобщей геномной регистрации в Российской Федерации» в целях улучшения качества раскрытия и расследования преступлений // Правовое государство: теория и практика. 2019. № 3 (57). С. 94-98.

3. Аминев Ф.Г., Анисимов А.В. Об организационном аспекте современной технологии всеобщей ДНК-регистрации граждан // Правовое государство: теория и практика. 2020. № 2 (60). С. 11-19.

4. Варданян А.В., Варданян Г.А. Теоретико-методологические проблемы криминалистической тактики в контексте современной модели уголовного процесса // Юристъ-Правоведъ. 2015. № 6. С. 5-10.

5. Аминев Ф.Г. Проблемные вопросы, возникающие при назначении новых родов и видов судебных экспертиз // Судебная экспертиза. 2018. № 2. С. 7-15.

6. Аминев Ф.Г., Аминев А.Ф. О возможностях использования генотипоскопического и дендрохронологического методов в криминалистической регистрации лесного массива России // Вестник криминалистики. 2019. № 1 (69). С. 6-12.

Дата поступления: 15.11.2020 


\title{
DIGITALIZATION IN REGULATING THE LIST OF FORENSIC EXAMINATIONS HELD IN NON-STATE FORENSIC EXPERT ORGANIZATIONS
}

\author{
ABDULLIN Ruslan Ramilevich, \\ Postgraduate Student of the Chair of Forensics of the Institute of Law, \\ Bashkir State University, Judge of the Ordzhonikidze District Court of Ufa, \\ Ufa, Russia. \\ E-mail: kriminalist2010@mail.ru
}

The study of the practice of investigating crimes indicates the need to use the achievements of high technologies, expressed in the most advanced form - digitalization. The possibilities of digitalization are being introduced into forensic activities, including non-state forensic organizations activities. Purpose: to analyze the problems of normative, scientific and methodological, material and technical regulation of the list of forensic examinations held outside state forensic organizations, with the development of solutions. Methods: the author uses empirical methods of observation, comparison, description, interpreting, interpretation of legal norms, comparative legal and statistical analysis, and formal logical methods of scientific knowledge. As a result of the study of various approaches, analysis of national and foreign regulatory legal acts, the author proves the necessity to develop a list of forensic examinations prohibited for production in non-state forensic organizations, which makes it possible to determine ways to increase the level of digitalization of forensic examinations by improving legal, scientific, methodological and organizational support of forensic expert activities in the Russian Federation.

Keywords: forensic expert activity; expert; non-state forensic organizations; digitalization; high-tech methods; list of examinations.

\section{References}

1. Aminev F.G., CHemeris A.V. On new methods of digitalization during genotyposcopic examination and genomic registration of the population of the Russian Federation. In Rossinskaya E.R., Lebedeva A.K., CHernyavskaya M.S. (eds.). Cifrovoj sled kak ob"ekt sudebnoj ekspertizy [Digital footprint as an object of forensic examination]. Moscow, Prospekt Publ., 2020, pp. 14-18. (In Russian).

2. Aminev F.G. On the need to adopt a federal law «On general genomic registration in the Russian Federation» in order to improve the quality of 
disclosure and investigation of crimes. Pravovoe gosudarstvo: teoriya i prakti$k a=$ The Rule-of-Law State: Theory and Practice, 2019, no. 3 (57), pp. 94-98. (In Russian).

3. Aminev F.G., Anisimov A.V. On the organizational aspect of modern technology for universal DNA registration of citizens. Pravovoe gosudarstvo: teoriya i praktika = The Rule-of-Law State: Theory and Practice, 2020, no. 2 (60), pp. 11-19. (In Russian).

4. Vardanyan A.V., Vardanyan G.A. Theoretical and methodological problems of criminalistic tactics in the context of the modern model of criminal procedure. YUrist"-Pravoved" = Jurist-Pravoved, 2015, no. 6, pp. 5-10. (In Russian).

5. Aminev F.G. Problematic issues arising from the appointment of new kinds and types of forensic examinations. Sudebnaya ekspertiza $=$ Forensic examination, 2018, no. 2, pp. 7-15. (In Russian).

6. Aminev F.G., Aminev A.F. On the possibilities of using genotyposcopic and dendrochronological methods in forensic registration of a forest in Russia. Vestnik kriminalistiki = Bulletin of Criminalistics, 2019, no. 1 (69), pp. 6-12. (In Russian).

Received: 15.11.2020 